\title{
Health literacy among schoolteachers in Çorum, Turkey
}

\author{
G. Yilmazel ${ }^{1}$ and F. Cetinkaya ${ }^{2}$
}

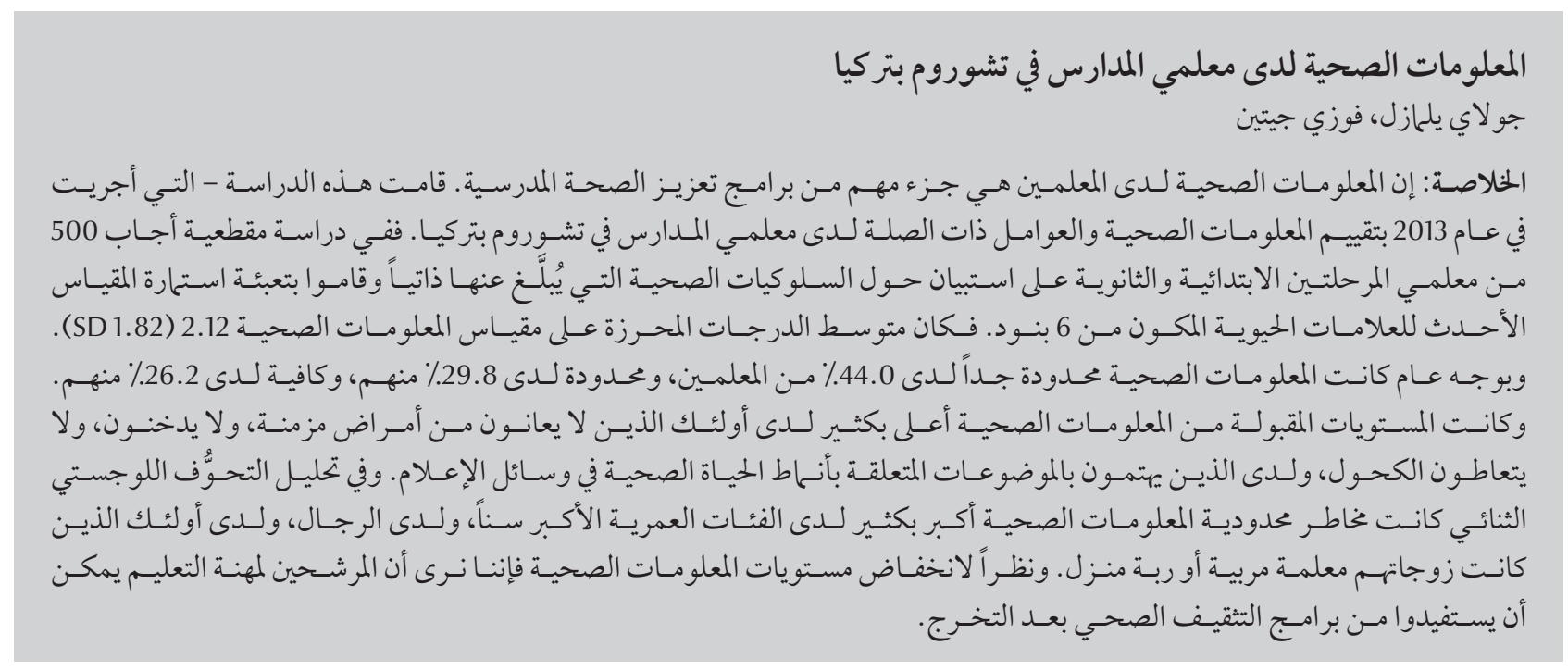

ABSTRACT Teachers' health literacy is an important part of school health promotion programmes. This study in 2013 assessed health literacy and related factors in schoolteachers in Çorum, Turkey. In a cross-sectional study, 500 primary and secondary teachers answered a questionnaire about self-reported health behaviours and completed the 6 -item Newest Vital Sign tool. The mean score on the health literacy scale was 2.12 (SD 1.82). Overall, $44.0 \%$ of the teachers had very limited, 29.8\% limited and 26.2\% adequate health literacy. Adequate health literacy levels were significantly higher among those without chronic disease, non-smokers, non-alcohol users and those interested in healthy lifestyle topics in the media. In binary logistic regression analysis, the risk of limited health literacy was significantly greater in the older age groups, in men and in those whose partner was an educator or a housewife. In view of the low health literacy levels, we suggest that teacher candidates could benefit from health education programmes after graduation.

\section{Niveau des connaissances en matière de santé des enseignants à Çorum (Turquie)}

RÉSUMÉ Les connaissances en matière de santé des enseignants sont une part importante des programmes de promotion de la santé en milieu scolaire. La présente étude menée en 2013 a évalué les connaissances en santé des enseignants ainsi que les facteurs en la matière à Çorum (Turquie). Dans une étude transversale, 500 enseignants d'établissements primaires et secondaires ont répondu à un questionnaire sur leurs comportements en santé autodéclarés puis aux questions de l'instrument en 6 items intitulé Newest Vital Sign scale. Le score moyen sur l'échelle des connaissances en matière de santé était de 2,12 (ET 1,82). Globalement, 44,0\% des enseignants avaient des connaissances très limitées, 29,8 \% des connaissances limitées et 26,2 \% des connaissances en santé adéquates. Les niveaux de connaissances en santé adéquats étaient nettement supérieurs chez les enseignants qui n'étaient pas atteints d'une maladie chronique, qui ne fumaient pas, qui ne consommaient pas d'alcool, ainsi que chez ceux qui s'intéressaient aux sujets portant sur les modes de vie sains dans les médias. À l'analyse de régression logistique binaire, le risque lié aux connaissances en santé limitées était significativement plus important dans les groupes plus âgés, chez les hommes et chez ceux dont le/la partenaire était un éducateur ou une femme au foyer. À la lumière de ces faibles niveaux de connaissances en santé, nous suggérons que les futurs enseignants puissent bénéficier de programmes d'éducation en santé après l'obtention de leur diplôme. 


\section{Introduction}

Health literacy is "the degree to which individuals have the capacity to obtain, process, and understand basic health information and services needed to make appropriate health decisions" (1). It is a wide spectrum of skills and competencies that people develop in order to seek out, comprehend, evaluate and use health information and concepts to make informed choices, reduce health risks and increase quality of life (2). Today, health literacy is seen as one of the most important influences on health care (3). Adequate health literacy allows individuals to make decisions and deliberate authorization in relation to health care, disease prevention and health promotion (4). In contrast, low health literacy affects individuals' level of knowledge about a disease and its symptoms as well as their ability to learn about disease management (5). In addition, it is more likely that these individuals use fewer preventive services and fewer medical services at the later stages of their disease. Poor health literacy reduces a patient's understanding of their illnesses, leading to lower levels of adherence with treatment. This too can greatly increase the likelihood of patients seeking treatment from emergency services which creates a financial burden on the health-care system, delays in inpatient treatment and higher cost of hospitalization (3,5-10).

Regardless of a country's development level, the health literacy levels of populations are found to be low all over the world. In 2011, in a study of health literacy conducted on over 8000 people aged $15+$ years in 8 European countries (Germany, Austria, Bulgaria, Netherlands, Ireland, Spain, Poland and Greece), respondents were classified into 4 groups - insufficient, problematic, adequate and very good-based on their Newest Vital Sign and Health Literacy Measurement Index scores. In the Netherlands $29.0 \%$ of respondents and in Bulgaria 62.0\% were in the insufficient and problematic groups, whereas in Ireland $60.0 \%$ of respondents and in the Netherlands $72.0 \%$ had very good scores. The rates of adequate and very good scores were the lowest in Bulgaria (37.0\%) and in Spain (42.0\%) (11).

Teachers' health literacy is increasingly seen as an important part of school health promotion programmes (12) and many studies have been conducted on how to improve mental health literacy among educators (13-15). In Turkey, studies on health literacy in the general population are limited and, to our knowledge, there has been no study among teachers. It is desirable that teachers' health literacy levels should be high because their roles involve teaching students about health information and health-related behaviours as a part of basic education at the primary and secondary school levels. Enhancing health literacy levels of teachers is necessary for the Project of Health Promoting Schools in Turkey. The objectives of the study reported here were to assess the health literacy levels and related factors in primary and secondary schoolteachers in Çorum province of Turkey.

\section{Methods}

\section{Study setting}

This cross-sectional study was carried out in 2013 in the province of Çorum, Turkey. Çorum is located inland in the central Black Sea region of Turkey and has a population of 527220 . This study was planned in accordance with the Helsinki Declaration and approved by the Erciyes University ethics committee.

\section{Study sampling}

The study population was primary and secondary schoolteachers in public schools in Çorum. Official records of the provincial directorate of education showed that there were 21 primary and 15 secondary schools with a total of 580 teachers in the province. In primary schools the teachers work as class teachers, whereas in secondary schools teachers have a specialty in teaching a specific subject (mathematics, history of literature, social science, science and technology, English language, religious and cultural science, sports or arts). We intended to sample the whole population of teachers, but the final analysis was done on questionnaires from 500 teachers. The response rate was $86.2 \%$. Reasons for non-participation were absence during the study period (5.0\%), incomplete questionnaires $(2.8 \%)$ and unwilling to fill out the questionnaire (6.0\%).

\section{Study tools}

A self-administered, anonymous questionnaire was used to collect data regarding each teacher's sociodemographic characteristics (age, sex, marital status, education, occupation of wife/ husband), occupational characteristics [type of teacher (class/subject), school level (primary/secondary), years of seniority], chronic health conditions, smoking, alcohol use; and self-reported health behaviours (general health perception, pattern of health service use, medical services preferred, interest in health subjects). All these items were analysed as independent variables. Self-reported health behaviours were assessed with the following questions: How would you assess your general health? (very good, good, moderate, bad, very bad; in analysis responses were collapsed into good, moderate, bad); How often do you go for preventive care regardless of whether you are sick or not? (always, sometimes, never); Which medical services do you visit first? (family physician, public/university hospital, special hospital/polyclinic); Which health subjects interest you in the media? (more than one option possible from: healthy life, alternative medicine, policies of the Ministry of Health, scientific discoveries, disease and treatment methods, medicine and medical products). 
Teachers' health literacy was assessed using the Newest Vital Sign (NVS) scale. The NVS is a 6-item instrument developed by Weiss et al. in 2005 as a literacy screening tool for health information (16). Participants are shown a nutrition label from an ice cream container specially designed for the test and 6 questions are verbally administered (e.g. how much ice cream has $60 \mathrm{~g}$ carbohydrate?). For each correct answer 1 point is given and the sum of the points indicates the level of health literacy. Health literacy levels were classified into 3 categories: very limited (score $0-1$ ), limited (score 2-3) and adequate (score 4-6). The scale was translated into Turkish by Ozdemir et al. in 2010 and the reliability and validity of the Turkish scale was assessed (17); the scale's internal consistency (Cronbach $\alpha=$ $0.70)$ and item validity $(r=0.52, P<$ 0.01 ) were found to be acceptable (17). Nonetheless, in our study the internal consistency of the scale was high (Cronbach $\alpha=0.71)$.

\section{Data collection}

For data collection, the researchers informed the teachers about the study, gave guarantees about confidentiality and took verbal consent from them. Teachers were allowed to respond to the questionnaire in their free time.
Each teacher needed approximately 10 minutes to complete the questionnaire.

\section{Data entry and analysis}

Health literacy scores and levels were calculated according to the guidelines of the NVS. For analysis we combined the very limited and limited health literacy categories to create binary categories: adequate and very limited/limited. The data were analysed using SPSS, version 17.0 software. Continuous data were presented as mean and standard deviation $(\mathrm{SD})$. In categorical data, the chi-squared test was used to compare groups. Also binary logistic regression analyses were used to predict significant factors for limited health literacy. Odds ratios (OR) and 95\% confidence inter$\operatorname{val}(\mathrm{CI})$ were calculated. $P<0.05$ values was considered statistically significant.

\section{Results}

\section{Background characteristics}

Of the study participants, $66.4 \%$ were male and $33.6 \%$ were female. The mean age was 42.9 (SD 8.8) years. Just over half of teachers $(53.8 \%)$ were working in primary schools and $46.2 \%$ in secondary schools; $47.6 \%$ were class teachers and $52.4 \%$ were subject teachers. Of the study group $41.0 \%$ had work experience of 11-20 years and the mean number of years of seniority was 19.6 (SD 9.3) years.

\section{Health literacy scores}

Table 1 shows the percentage of correct responses for each of the $6 \mathrm{NVS}$ questions; $46.2 \%$ of the whole group gave correct responses to question 4, 41.4\% to question 5 and $36.8 \%$ to question 1 . Women gave significantly more correct responses than did men for all items in the scale except for question 3 (about the grammes of saturated fat in 1 serving of ice cream).

The mean health literacy score of the whole sample was 2.12 (SD 1.82), within a score range of $0-6$. The distribution of teachers' health literacy scores showed that $44.0 \%$ had a health literacy score classified as very limited, $29.8 \%$ as limited and $26.2 \%$ as adequate (Table 2 ).

\section{Health literacy level by demographic and educational characteristics}

The rate of adequate health literacy level according to the demographic and educational characteristics of teachers is shown in Table 3. Significant differences were found in adequate health literacy according to individual's age group, sex, spouse's occupation, graduation level and years of seniority. Adequate health literacy levels were higher in the 25-34 age group compared with other age

\begin{tabular}{|c|c|c|c|c|c|c|}
\hline \multirow[t]{2}{*}{ Item\# } & \multirow[t]{2}{*}{ Abbreviated item } & \multicolumn{3}{|c|}{$\%$ correct response } & \multirow[t]{2}{*}{$x^{2}$} & \multirow[t]{2}{*}{$P$-value } \\
\hline & & $\begin{array}{l}\text { Females } \\
(n=168)\end{array}$ & $\begin{array}{c}\text { Males } \\
(n=332)\end{array}$ & $\begin{array}{c}\text { Total } \\
(n=500)\end{array}$ & & \\
\hline 1 & $\begin{array}{l}\text { How many calories in entire } \\
\text { ice cream carton? }\end{array}$ & 47.0 & 31.6 & 36.8 & 11.371 & 0.001 \\
\hline 2 & $\begin{array}{l}\text { How much ice cream has } 60 \mathrm{~g} \\
\text { carbohydrates? }\end{array}$ & 29.2 & 20.8 & 23.6 & 4.348 & 0.037 \\
\hline 3 & $\begin{array}{l}\text { How many grammes of } \\
\text { saturated fat in } 1 \text { serving? }\end{array}$ & 39.9 & 33.7 & 35.8 & 1.833 & 0.176 \\
\hline 4 & $\begin{array}{l}\text { What \% of } 2500 \text { calorie } \\
\text { daily intake is this pint of ice } \\
\text { cream? }\end{array}$ & 57.7 & 40.4 & 46.2 & 13.551 & $<0.001$ \\
\hline 5 & $\begin{array}{l}\text { If allergic to peanuts, can you } \\
\text { eat this ice cream? }\end{array}$ & 57.7 & 33.1 & 41.4 & 27.839 & $<0.001$ \\
\hline 6 & If not, why not? & 42.9 & 20.8 & 28.2 & 26.845 & $<0.001$ \\
\hline
\end{tabular}




\begin{tabular}{|c|c|c|c|c|c|c|}
\hline \multirow[t]{2}{*}{ Health literacy level (NVS score ${ }^{a}$ ) } & \multicolumn{2}{|c|}{$\begin{array}{c}\text { Males } \\
(n=332)\end{array}$} & \multicolumn{2}{|c|}{$\begin{array}{l}\text { Females } \\
(n=168)\end{array}$} & \multicolumn{2}{|c|}{$\begin{array}{c}\text { Total } \\
(\boldsymbol{n}=\mathbf{5 0 0})\end{array}$} \\
\hline & No. & $\%$ & No. & $\%$ & No. & $\%$ \\
\hline Very limited (score $0-1$ ) & 168 & 50.6 & 52 & 31.0 & 220 & 44.0 \\
\hline Limited (score 2-3) & 103 & 31.0 & 46 & 27.3 & 149 & 29.8 \\
\hline Adequate (score 4-6) & 61 & 18.4 & 70 & 41.7 & 131 & 26.2 \\
\hline
\end{tabular}

${ }^{a}$ Score range 0-6.

groups $(P<0.001)$ and in women than in men $(P<0.001)$. Compared with other occupational groups, adequate health literacy levels were higher in those whose wife/husband was a health professional $(P<0.001)$, among graduates $(P=0.028)$ and among those with $\leq 10$ years' experience $(P=0.002)$.
Health literacy level by selfreported health behaviours

Table 4 shows self-reported health behaviours according to the health

\begin{tabular}{|c|c|c|c|c|c|c|c|}
\hline \multirow[t]{3}{*}{ Characteristic } & \multirow{3}{*}{$\begin{array}{l}\text { Total } \\
\text { No. }\end{array}$} & \multicolumn{4}{|c|}{ Health literacy level } & \multirow[t]{3}{*}{$x^{2}$} & \multirow[t]{3}{*}{$P$-value } \\
\hline & & \multicolumn{2}{|c|}{ Adequate } & \multicolumn{2}{|c|}{ Limited/Very limited } & & \\
\hline & & No. & $\%$ & No. & $\%$ & & \\
\hline Age group (years) & & & & & & 21.35 & $<0.001$ \\
\hline $25-34$ & 93 & 41 & 44.1 & 52 & 55.9 & & \\
\hline $35-49$ & 288 & 70 & 24.3 & 218 & 75.7 & & \\
\hline $50-64$ & 119 & 20 & 16.8 & 99 & 83.2 & & \\
\hline Sex & & & & & & 31.30 & $<0.001$ \\
\hline Male & 332 & 61 & 18.4 & 281 & 82.2 & & \\
\hline Female & 168 & 70 & 41.7 & 98 & 58.3 & & \\
\hline Marital status & & & & & & 0.014 & 0.905 \\
\hline Married & 463 & 121 & 26.1 & 342 & 73.9 & & \\
\hline Single/divorced & 37 & 10 & 27.0 & 27 & 73.0 & & \\
\hline Spouse's occupation $(n=463)$ & & & & & & 16.99 & 0.001 \\
\hline Educator & 188 & 60 & 31.9 & 128 & 68.1 & & \\
\hline Health professional & 30 & 12 & 40.0 & 18 & 60.0 & & \\
\hline Housewife & 160 & 24 & 15.0 & 136 & 85.0 & & \\
\hline Other sector/self-employed & 85 & 25 & 29.4 & 60 & 70.6 & & \\
\hline Graduation level & & & & & & 4.848 & 0.028 \\
\hline High school/pre-graduate & 102 & 18 & 17.6 & 84 & 82.4 & & \\
\hline Bachelor degree and above & 398 & 113 & 28.4 & 285 & 71.6 & & \\
\hline Type of teacher & & & & & & 2.244 & 0.134 \\
\hline Class teacher & 238 & 55 & 23.1 & 183 & 76.9 & & \\
\hline Subject teacher & 262 & 76 & 29.0 & 186 & 71.0 & & \\
\hline Type of school worked in & & & & & & 0.834 & 0.361 \\
\hline Primary & 269 & 66 & 24.5 & 203 & 75.5 & & \\
\hline Secondary & 231 & 65 & 28.1 & 166 & 71.9 & & \\
\hline Years of seniority & & & & & & 15.30 & 0.002 \\
\hline$\leq 10$ & 85 & 34 & 40.0 & 51 & 60.0 & & \\
\hline $11-20$ & 205 & 57 & 27.8 & 148 & 72.2 & & \\
\hline $21-30$ & 130 & 28 & 21.5 & 102 & 78.5 & & \\
\hline$>31$ & 80 & 12 & 15.0 & 68 & 85.0 & & \\
\hline Total & 500 & 131 & 26.2 & 369 & 73.8 & & \\
\hline
\end{tabular}


literacy level of teachers. Among the whole sample of teachers $79.2 \%$ had positive health perceptions, $63.4 \%$ reported that they saw a doctor for check-ups always/sometimes and $55.2 \%$ stated that they primarily visited a family physician for health problems. Compared with those with limited/ very limited health literacy, slightly fewer teachers with adequate health literacy had a positive health perception or saw a doctor for check-ups. There was a significant difference in health literacy levels of teachers according to which medical service they primarily used; teachers who primarily visited public/university hospitals or special hospitals/polyclinics were more likely to have adequate health literacy than those who visited a family physician $(P$ $<0.05$ ).

The rate of adequate health literacy according to whether a teacher had a chronic disease or not are also shown in Table 4. Having one or more chronic health conditions was reported by $36.4 \%$ of teachers. Chronic disease was found to be associated with age and seniority. Chronic disease was more prevalent in those of older age groups (35-49 and 50-64 years) $(P<0.001)$ and longer years of experience $(\geq 11$ years) $(P<0.001)$. Health literacy was adequate in $25.3 \%$ of teachers with chronic disease and in $26.7 \%$ of those without chronic disease and there was no significant difference in the level of health literacy according to individuals' chronic disease status; $(P>0.05)$.

Health literacy levels of teachers according to smoking and alcohol use showed that a quarter of teachers $(25.2 \%)$ reported being a current smoker and $(23.8 \%)$ were alcohol users. Among teachers with adequate health literacy, $24.5 \%$ were non -smokers and $25.2 \%$ were non-alcohol users and there was no difference in the health literacy level of teachers according to smoking and alcohol use $(P>$ 0.05) (Table 4).

\begin{tabular}{|c|c|c|c|c|c|c|c|}
\hline \multirow[t]{3}{*}{ Variable } & \multirow{3}{*}{$\begin{array}{l}\text { Total } \\
\text { No. }\end{array}$} & \multicolumn{4}{|c|}{ Health literacy level } & \multirow[t]{3}{*}{$x^{2}$} & \multirow[t]{3}{*}{$P$-value } \\
\hline & & \multicolumn{2}{|c|}{ Adequate } & \multicolumn{2}{|c|}{ Limited/Very limited } & & \\
\hline & & No. & $\%$ & No. & $\%$ & & \\
\hline General health perception & & & & & & 0.193 & 0.661 \\
\hline Good & 396 & 102 & 25.8 & 294 & 74.2 & & \\
\hline Moderate/bad & 104 & 29 & 27.9 & 75 & 72.1 & & \\
\hline Visit a doctor for check-ups & & & & & & 2.074 & 0.355 \\
\hline Always/sometimes & 317 & 80 & 25.2 & 237 & 74.8 & & \\
\hline Never & 183 & 51 & 27.9 & 132 & 72.1 & & \\
\hline Medical service used primarily & & & & & & 8.568 & 0.014 \\
\hline Family physician & 276 & 58 & 21.0 & 218 & 79.0 & & \\
\hline Public/university hospital & 129 & 42 & 32.6 & 87 & 67.4 & & \\
\hline Special hospital/polyclinic & 95 & 31 & 32.6 & 64 & 67.4 & & \\
\hline Chronic disease & & & & & & 0.127 & 0.722 \\
\hline Yes & 182 & 46 & 25.3 & 136 & 74.7 & & \\
\hline No & 318 & 85 & 26.7 & 233 & 73.3 & & \\
\hline Smoking habit & & & & & & 0.056 & 0.813 \\
\hline Current smoker & 126 & 32 & 25.4 & 94 & 74.6 & & \\
\hline Quitter or non-smoker & 374 & 99 & 26.5 & 275 & 73.5 & & \\
\hline Alcohol use & & & & & & 0.189 & 0.663 \\
\hline Current user & 119 & 33 & 27.7 & 86 & 72.3 & & \\
\hline Non-user & 381 & 98 & 25.7 & 283 & 74.3 & & \\
\hline Interest in healthy life issues ${ }^{a}$ & & & & & & 7.356 & 0.007 \\
\hline Interested & 363 & 107 & 29.4 & 256 & 70.6 & & \\
\hline Not interested & 137 & 24 & 17.5 & 113 & 82.5 & & \\
\hline Interest in alternative medicine & & & & & 100 & 2.565 & 0.109 \\
\hline Interested & 170 & 52 & 30.6 & 118 & 69.4 & & \\
\hline Not interested & 330 & 79 & 23.9 & 251 & 76.1 & & \\
\hline Total & 500 & 131 & 26.2 & 369 & 73.8 & & \\
\hline
\end{tabular}

${ }^{a}$ For example, nutrition, physical activity, quitting smoking. 
The health literacy levels of teachers were analysed according to their interest in information from the media about healthy living and alternative medicine (Table 4). Health literacy was significantly higher among teachers who reported that they were interested in topics related to healthy lifestyles $(P=0.007)$. In contrast, an interest in alternative medicine had no significant affect on health literacy $(P$ $=0.109$ ).

\section{Factors predicting limited health literacy levels}

Table 5 shows the significant factors predicting limited health literacy levels of teachers in the binary logistic regression analysis. Limited health literacy risk was 3.29-fold higher in the 35-49 year age group and 2.85-fold higher in the 50-64 year age group than in the 25-34 year age groups. Also the risk of having limited health literacy was significantly higher in men than women (OR 3.18); in those whose partner was an educator (OR 1.95), housewife (OR 2.27) or other/self-employed (OR 2.77) than those whose partner was a health-care professional. The effects of other independent variables were not significant.

\section{Discussion}

The mean score of all teachers on the NVS was 2.12 (SD 1.82) out of a maximum score of 6 , therefore demonstrating an overall limited level of health literacy among the study sample. In another study of health literacy in Turkey, the mean score of the NVS was 2.60 (SD 0.08) in individuals aged $\geq$ 17 years in Bursa and in $28.1 \%$ of them the health literacy level was adequate (17). In Ankara too, it was found that $29.6 \%$ of university students had an adequate level of health literacy (18). In studies conducted abroad, the NVS scores and the rate of adequate health literacy were relatively higher than in Turkey. Adequate health literacy levels were found in $55.9 \%$ of adults in Serbia (19), 26.0-50.0\% in the United States of America (USA) (20-22), 79.0\% in Australia (23), 75.5\% in Japan (24), $61.0 \%$ in England (25) and $43.0 \%$ in Ireland (26). When comparing the level of health literacy between the current study and other studies we found similar results with our study and Mississippi in the USA (22).

Less than half of the study group were able to respond correctly to all the items of the scale. The ratio of responses indicated a higher level of health literacy in women teachers. However, health literacy skills were inadequate in both sexes. We also found that adequate health literacy level varied according to age group and was significantly lower in those aged 50-64 years than in other age groups. In other studies, age was found to influence health literacy $(17,19,23,24,27,28)$. It has been suggested that health literacy decreases with declining age as a result of reductions in cognitive function and sensory abilities (29-31). Another factor we found to affect health literacy level was the individual's sex, with women having better health literacy than men. In many studies, it was established that a higher level of education increased the adequate health literacy levels by creating a positive and synergistic effect on women's health $(19,23,24,27,28)$.

In the present study, health literacy was significantly higher in teachers whose wife/husband worked as health professional. This agrees with the results of another study showing that adequate health literacy levels were higher in individuals having a health professional among their family members (18). Presumably having a health professional within the household can increase knowledge and

\begin{tabular}{|c|c|c|c|c|}
\hline Independent variable ${ }^{a}$ & $\beta$ & $P$-value & OR & $95 \% \mathrm{Cl}$ \\
\hline Age group (years) & & 0.037 & & \\
\hline $25-34$ & Ref. & & & \\
\hline $35-49$ & -1.192 & 0.010 & 0.30 & $0.12-0.76$ \\
\hline $50-64$ & -1.050 & 0.119 & 0.35 & $0.09-1.31$ \\
\hline Sex & & $<0.001$ & & \\
\hline Male & Ref. & & & \\
\hline Female & 1.158 & $<0.001$ & 3.18 & $1.76-5.77$ \\
\hline Spouse's occupation & & 0.208 & & \\
\hline Health professional & Ref. & & & \\
\hline Educator & -0.668 & 0.140 & 0.51 & $0.21-1.25$ \\
\hline Housewife & -0.822 & 0.087 & 0.44 & $0.17-1.13$ \\
\hline Other sector/self-employed & -1.019 & 0.048 & 0.36 & $0.24-0.99$ \\
\hline Constant & -0.970 & 0.349 & 0.379 & \\
\hline
\end{tabular}

a Variables: age group, sex, marital status, occupation of wife/husband, organization, type of teacher, graduation level, years of seniority, general health perception, visit doctor for check-ups, medical services used primarily, chronic disease status, smoking habit and alcohol use.

Ref. = reference group; $O R=$ odds ratio; $C I=$ confidence interval. 
awareness related to health and disease among other family members. We also found that health literacy differed according to individuals' educational level and was significantly higher in those who had a bachelor's degree. This is consistent with the results of other studies from other countries showing that individuals with higher levels of education had adequate health literacy levels $(17,19,23,24,28,29)$. Adequate health literacy levels in the present study were significantly lower among those with $\geq 31$ years' of seniority. Other studies have also shown that the duration of graduation from formal education leads was associated with lower health literacy (30-32).

Teachers who had chronic diseases and those who evaluated their general health as moderate/poor had lower adequate health literacy levels. This agrees with research showing a strong relationship between weak physical and psychological well-being and lower health literacy, as people with limited health literacy were more likely to evaluate their health as moderate/ poor $(1,24,33)$ and people with chronic health problems have lower health literacy levels $(1,21,34)$.
We found that individuals who preferred to visit a family physician for an initial health problem were less likely to have adequate health literacy levels than those whose utilized hospitals. In contrast, in other studies it was found that adequate health literacy levels were higher in people utilizing primarily primary health-care services $(23,35,36)$.

In the European Health Literacy Study, smoking and alcohol use were shown to be risk factors associated with low health literacy (32). In addition, national and international studies showed that adequate health literacy levels were higher among non-smokers and non-alcohol users $(18,24,37,38)$. We also found that in teachers with an adequate health literacy level the rates of non-smoking and non-alcohol using were higher.

Media that can reach a wide audience of individuals can be effective in improving healthy lifestyle behaviours and we found that teachers with an interest in healthy lifestyle topics in the media had significantly higher rates of adequate health literacy. This agrees with the results of other studies (39-44).
Individuals' age group, sex and spouses' occupation were identified as demographic variables that had a significant impact on limited health literacy levels in our study, which agrees with many other studies showing the impact of age and sex on limited health literacy $(19,22-25,27,28)$.

\section{Conclusion}

Levels of health literacy in primary and secondary schoolteachers in Çorum were found to be limited. Knowledge of health literacy in schoolteachers should be improved. It may be a useful approach to focus on the health curriculum at all levels of the education system and provide teacher candidates with health education programmes after graduation.

\section{Acknowledgements}

Thanks to Mr Tony Wheeler for language editions and proofreading.

\section{Funding: None.}

Competing interests: None declared.

\section{References}

1. Healthy people 2010: understanding and improving health Washington (DC): United States Department of Health and Human Services; 2010. ((http://www.health.gov/communication/ literacy/quickguide/factsbasic.htm, accessed 12 July 2013).

2. Zarcadoolas C, Pleasant A, Greer DS. Understanding health literacy: an expanded model. Health Promot Int. 2005 Jun;20(2):195-203. PMID:15788526

3. McCray AT. Promoting health literacy. J Am Med Inform Assoc. 2005 Mar-Apr;12(2):152-63. PMID:15561782

4. Sørensen K, Van den Broucke S, Fullam J, Doyle G, Pelikan J, Slonska Z, et al.; (HLS-EU) Consortium Health Literacy Project European. Health literacy and public health: a systematic review and integration of definitions and models. BMC Public Health. 2012;12(80):80. PMID:22276600

5. Dewalt DA, Berkman ND, Sheridan S, Lohr KN, Pignone MP. Literacy and health outcomes: a systematic review of the literature. J Gen Intern Med. 2004 Dec;19(12):1228-39. PMID:15610334

6. Nielsen-Bohlman L, Panzer MA, Kindig DA. Health literacy: a prescription to end confusion. Washington (DC): Institute of Medicine of the National Academies, National Academies Press; 2004.

7. Baker DW, Gazmararian JA, Williams MV, Scott T, Parker RM, Green D, et al. Health literacy and use of outpatient physician services by Medicare managed care enrollees. J Gen Intern Med. 2004 Mar;19(3):215-20. PMID:15009775

8. Howard DH, Gazmararian J, Parker RM. The impact of low health literacy on the medical costs of Medicare managed care enrollees. Am J Med. 2005 Apr;118(4):371-7. PMID:15808134

9. von Wagner C, Steptoe A, Wolf MS, Wardle J. Health literacy and health actions: a review and a framework from health psychology. Health Educ Behav. 2009 Oct;36(5):860-77. PMID:18728119

10. Frisch AL, Camerini L, Diviani N, Schulz PJ. Defining and measuring health literacy: how can we profit from other literacy domains? Health Promot Int. 2012 Mar;27(1):117-26. PMID:21724626

11. Pelikan JM, Röthlın F, Ganahl K. Comparative report on health literacy in eight EU member states, The European Health Literacy Project 2009- 2012. Maastricht: HLS-EU Consortium; 2012.

12. Peterson FL, Cooper RJ, Laird JM. Enhancing teacher health literacy in school health promotion: a vision for the new millennium. J Sch Health. 2001 Apr;71(4):138-44. PMID:11354982

13. Whitley J, Smith JD, Vaillancourt T. Promoting mental health literacy among educators: critical in school-based prevention and intervention. Can J Sch Psychol. 2012;28(1):56-70. 
14. Jorm AF, Kitchener BA, Sawyer MG, Scales H, Cvetkovski S. Mental health first aid training for high school teachers: a cluster randomized trial. BMC Psychiatry. 2010;10(51):51. PMID:20576158

15. Blain-Arcaro C, Smith JD, Cunningham C, Vaillancourt T, Rimas $\mathrm{H}$. Contextual attributes of indirect bullying situations that influence teachers' decisions to intervene. J Sch Violence. 2012;11:226-45.

16. Weiss BD, Mays MZ, Martz W, Castro KM, DeWalt DA, Pignone $M P$, et al. Quick assessment of literacy in primary care: the newest vital sign. Ann Fam Med. 2005 Nov-Dec;3(6):514-22. PMID:16338915

17. Ozdemir H, Alper Z, Uncu Y, Bilgel N. Health literacy among adults: a study from Turkey. Health Educ Res. 2010 Jun;25(3):464-77. PMID:20080808

18. Ikinci S, Eser S, Piyal B, Calıskan D, Ocaktan ME, Akdur R. Health literacy status of a two-year degree health programmes of university students (Ankara University sample). XV National Public Health Congress Book. Ankara: Hasuder Press; 2012.

19. Jovic-Vranes A, Bjegovic-Mikanovic V. Which women patients have better health literacy in Serbia? Patient Educ Couns. 2012 Oct;89(1):209-12. PMID:22749876

20. Kirk JK, Grzywacz JG, Arcury TA, Ip EH, Nguyen HT, Bell RA, et al. Performance of health literacy tests among older adults with diabetes. J Gen Intern Med. 2012 May;27(5):534-40. PMID:22095571

21. Shah LC, West P, Bremmeyr K, Savoy-Moore RT. Health literacy instrument in family medicine: the "newest vital sign" ease of use and correlates. J Am Board Fam Med. 2010 MarApr;23(2):195-203. PMID:20207930

22. Zoellner J, You W, Connell C, Smith-Ray RL, Allen K, Tucker $\mathrm{KL}$, et al. Health literacy is associated with healthy eating index scores and sugar-sweetened beverage intake: findings from the rural Lower Mississippi Delta. J Am Diet Assoc. 2011 Jul;111(7):1012-20. PMID:21703379

23. Adams RJ, Appleton SL, Hill CL, Dodd M, Findlay C, Wilson $\mathrm{DH}$. Risks associated with low functional health literacy in an Australian population. Med J Aust. 2009 Nov 16;191(10):530-4. PMID:19912083

24. Tokuda Y, Doba N, Butler JP, Paasche-Orlow MK. Health literacy and physical and psychological wellbeing in Japanese adults. Patient Educ Couns. 2009 Jun;75(3):411-7. PMID:19403259

25. Boxell EM, Smith SG, Morris M, Kummer S, Rowlands G Waller J, et al. Increasing awareness of gynecological cancer symptoms and reducing barriers to medical help seeking: does health literacy play a role? J Health Commun. 2012;17(3) Suppl 3:265-79. PMID:23030575

26. Sahm LJ, WolfMS, Curtis LM, McCarthy S. Prevalence of limited health literacy among Irish adults. J Health Commun. 2012;17(3) Suppl 3:100-8. PMID:23030564

27. Patel PJ, Joel S, Rovena G, Pedireddy S, Saad S, Rachmale R, et al. Testing the utility of the newest vital sign (NVS) health literacy assessment tool in older African-American patients. Patient Educ Couns. 2011 Dec;85(3):505-7. PMID:21514089

28. Marks JR, Schectman JM, Groninger H, Plews-Ogan ML. The association of health literacy and socio-demographic factors with medication knowledge. Patient Educ Couns. 2010 Mar;78(3):372-6. PMID:19773144
29. National Action Plan to Improve Health Literacy. Washington (DC): Office of Disease Prevention and Health Promotion, United States Department of Health and Human Services; 2010.

30. Davis TC, Long SW, Jackson RH, Mayeaux EJ, George RB, Murphy PW, et al. Rapid estimate of adult literacy in medicine: a shortened screening instrument. Fam Med. 1993 Jun;25(6):391-5. PMID:8349060

31. Gausman Benson J, Forman WB. Comprehension of written health care information in an affluent geriatric retirement community: use of the Test of Functional Health Literacy. Gerontology. 2002 Mar-Apr;48(2):93-7. PMID:11867931

32. Downey LV, Zun LS. Assessing adult health literacy in urban healthcare settings. J Natl Med Assoc. 2008 Nov;100(11):13048. PMID:19024227

33. Wolf MS, Gazmararian JA, Baker DW. Health literacy and functional health status among older adults. Arch Intern Med. 2005 Sep 26;165(17):1946-52. PMID:16186463

34. Sudore RL, Yaffe K, Satterfield S, Harris TB, Mehta KM, Simonsick EM, et al. Limited literacy and mortality in the elderly: the health, aging, and body composition study. J Gen Intern Med. 2006 Aug;21(8):806-12. PMID:16881938

35. Cho YI, Lee SYD, Arozullah AM, Crittenden KS. Effects of health literacy on health status and health service utilization amongst the elderly. Soc Sci Med. 2008 Apr;66(8):1809-16. PMID:18295949

36. Hudon C, Fortin M, Poitras ME, Almirall J. The relationship between literacy and multimorbidity in a primary care setting. BMC Fam Pract. 2012;13(33):33. PMID:22536833

37. Baker DW, WolfMS, Feinglass J, Thompson JA, Gazmararian JA, Huang J. Health literacy and mortality among elderly persons. Arch Intern Med. 2007 Jul 23;167(14):1503-9. PMID:17646604

38. Wolf MS, Gazmararian JA, Baker DW. Health literacy and health risk behaviors among older adults. Am J Prev Med. 2007 Jan;32(1):19-24. PMID:17184964

39. Nutbeam D. Health literacy as a public health goal: a challenge for contemporary health education and communication strategies into the 21st Century. Health Promot Int. 2000;15(3):259 67.

40. Jensen JD, King AJ, Davis LA, Guntzviller LM. Utilization of internet technology by low-income adults: the role of health literacy, health numeracy, and computer assistance. J Aging Health. 2010 Sep;22(6):804-26. PMID:20495159

41. Birru MS, Monaco VM, Charles L, Drew H, Njie V, Bierria T, et al. Internet usage by low-literacy adults seeking health information: an observational analysis. J Med Internet Res. 2004 Sep 3;6(3):e25. PMID:15471751

42. Sarkar U, Karter AJ, Liu JY, Adler NE, Nguyen R, Lopez A, et al. The literacy divide: health literacy and the use of an internetbased patient portal in an integrated health system-results from the diabetes study of northern California (DISTANCE). J Health Commun. 2010;15(2) Suppl 2:183-96. PMID:20845203

43. Wakefield MA, Loken B, Hornik RC. Use of mass media campaigns to change health behaviour. Lancet. 2010 Oct 9;376(9748):1261-71. PMID:20933263

44. Noar SM. A 10-year retrospective of research in health mass media campaigns: where do we go from here? J Health Commun. 2006;11(1):21-42. PMID:16546917 